\title{
Implementasi Metode Waterfall Pada Rancang Bangun Sistem Informasi Akuntansi Penerimaan dan Pengeluaran Kas
}

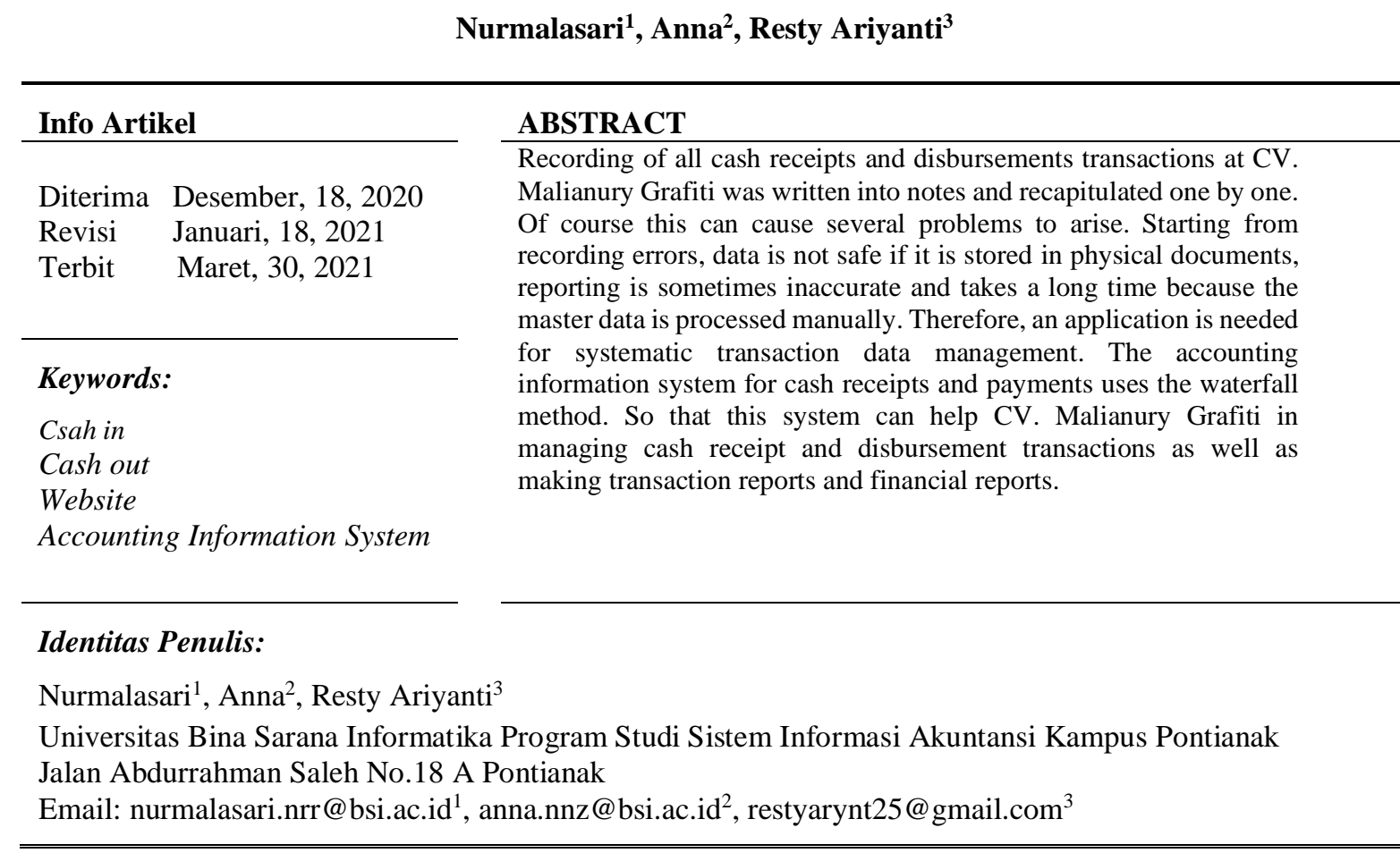

\section{PENDAHULUAN}

Di era digital ini, peranan sistem informasi akuntansi sangatlah penting bagi perusahaan untuk dapat menunjang setiap kegiatan operasionalnya dan membantu dalam proses pengambilan keputusan. Sebagian besar banyak perusahaan yang telah menggunakan sistem informasi untuk mendukung proses bisnisnya agar dengan penggunaan system tersebut, dapat tercapai keunggulan kompetitif perusahaan. Salah satu sistem informasi tersebut adalah sistem informasi akuntansi. Sistem informasi akuntansi merupakan subsistem dari sistem informasi yang menyediakan informasi akuntansi dan keuangan, bersama informasi lainnya yang diperoleh dalam transaksi akuntansi yang rutin [1].

CV. Malianury Grafiti merupakan sebuah perusahaan yang bergerak di bidang usaha jasa percetakan, yang melayani pemesanan nota, buku yasin, kalender, undangan, agenda serta komik. CV Malianury Grafiti adalah tempat percetakan dengan harga yang terjangkau tetapi kualitas produk menjadi keutamaan. Pelanggan CV. Malianury Grafiti bisa perorangan maupun perusahaan yang ingin melakukan percetakan dengan cara memesan terlebih dahulu. Kendala yang dihadapi CV Malianury Grafiti adalah pencatatan laporan keuangan yang berjalan masih sederhana bagi perusahaan karena hanya menggunakan Microsoft Excel sehingga dapat menimbulkan beberapa masalah seperti hilangnya file laporan dikarenakan terjadi error pada pengolahan data di Microsoft Excel, pembuatan laporan yang tidak akurat dan lama diproses dikarenakan perhitungan laporan dilakukan rekap data satu per satu. Untuk itu diperlukan adanya sebuah aplikasi yang dapat membantu mereka dalam mengelola data.

Pada penelitian ini digunakan metode waterfall dalam pembuatan sistem informasi akuntansi penerimaan dan pengeluaran kas berbasis website. Sehingga aplikasi ini dapat digunakan oleh pihak CV.Malianury Grafiti dalam mengelola transaksi penerimaan dan pengeluaran kas dengan baik, akurat dan cepat.

\section{METODE}

\subsection{Metode Penelitian}

Pengumpulan data adalah faktor yang paling penting dalam sebuah penelitian. Hal ini berkaitan dengan cara mengumpulkan data, siapa sumbernya, dan apa alat yang digunakan. Peneliti menggunakan teknik 
pengumpulan data dan metode penelitian deskriptif. Penelitian deskriptif merupakan suatu metode penelitian yang ditujukan untuk menggambarkan fenomena-fenomena yang ada, yang berlangsung pada saat ini atau saat yang lampau. Teknik pengumpulan data yang digunakan dalam penelitian ini yaitu observasi, wawancara dan studi pustaka [2].

\subsection{Metode Pengembangan Software}

Pada penelitian ini, penulis menggunakan model waterfall sebagai metode pengembangan perangkat lunak. Model waterfall sering disebut dengan model sekuensial linier (sequential linier) atau alur hidup perangkat lunak secara sekuensial atau terurut mulai dari analisis kebutuhan perangkat lunak, desain, pembuatan kode program, pengujian, dan pendukung (support). Berikut tahapan-tahapan dari model waterfall

1. Analisa Kebutuhan Software

Analisa kebutuhan yaitu diawali dengan mencari kebutuhan dari keseluruhan sistem yang akan diaplikasikan ke dalam bentuk software. Pada tahap ini penulis melakukan penentuan kebutuhan, hal ini dilakukan dengan cara mempelajari sistem yang telah ada di CV. Malianury Grafiti seperti fungsi software yang diinginkan. Kinerja (performance) dan interface terhadap elemen lainnya, seperti hardware, software, lain dan database sehingga Analisa kebutuhan perangkat lunak juga didasari dari data-data yang diperoleh dari teknik pengumpulan data.

2. Desain

Desain perangkat lunak adalah proses multi langkah yang fokus pada desain pembuatan program perangkat lunak yang terdiri dari pemodelan sistem menggunakan use case diagram dan activity diagram, pemodelan basis data menggunakan ERD dan LRS, struktur navigasi, dan pemodelan tampilan.

3. Pembuatan Kode Program

Rancangan sistem dijadikan sebagai untuk pengimplementasian atau pembuatan kode program. Tahapan ini berkaitan dengan pengkodean (coding) menggunakan PHP, HTML, CSS, jQuery, Javascript dan bantuan dari Bootstraps untuk menghasilkan aplikasi berbasis web.

4. Pengujian

Untuk meminimalisir kesalahan dan memastikan keluaran yang dihasilkan sesuai dengan yang diinginkan Pengujian yang dilakukan menggunakan metode black box testing.

\subsection{Sistem Informasi Akuntansi}

Menurut [1] menyatakan bahwa "Sistem informasi akuntansi didefinisikan sebagai sistem informasi yang merubah data transaksi bisnis menjadi informasi keuangan yang berguna bagi pemakainya".

sistem informasi akuntansi adalah suatu komponen organisasi yang mengumpulkan, mengklasifikasikan, mengolah, menganalisa dan mengkomunikasikan informasi finansial dan pengambilan keputusan yang relevan kepada pihak luar dan dalam perusahaan [3]. Disimpulkan dari penjelasan diatas bahwa Sistem informasi akuntansi adalah suatu subsistem dari SIM yang menyediakan informasi akuntansi dan keuangan dan transaksi bisnis menjadi informasi keuangan yang berguna bagi pemakainya.

\subsection{Pengertian Website}

Website digunakan sebagai tempat pertukaran dan penyebaran informasi dengan sangat cepat dan efisien. Website yang dibutuhkan saat ini adalah website dinamis yang diperlukan ketelitian dalam proses pembuatannya sehingga menghasilkan output memuaskan dan sesuai dengan kebutuhan pengguna. Konsep pemrograman web tersebut secara terurut mulai dari paling dasar sampai ke hal yang lebih kompleks. Semakin banyak perusahaan yang menggunakan aplikasi berbasis website sebagai salah satu media pemasaran yang sangat membantu saat ini [4].

\subsection{Penerimaan dan Pengeluaran Kas}

Kas masuk yang disebut juga sebagai penerimaan kas ini berasal dari kegiatan rutin perusahaan, misalnya penjualan tunai, penerimaan piutang maupun penerimaan kas yang bersifat tidak rutin misalnya penyertaan modal, penjualan saham, penjualan aktiva perusahaan[5]. Selain itu, kas masuk juga diartikan sebagai suatu transaksi yang menimbulkan bertambahnya saldo kas dan bank milik perusahaan yang diakibatkan adanya 
penjualan kecil produksi, penerimaan piutang maupun hasil transaksi lainnya yang menyebabkan bertambahnya kas[6].

Sedangkan pengeluaran kas (kas keluar) adalah berupa pengeluaran yang sifatnya kontinyu, seperti pembayaran bunga, dividen dan pembayaran pajak. Arus kas berlangsung terus menerus selama perusahaan menjalankan kegiatannya[5]. Digunakan jurnal khusus untuk mencatat semua pengeluaran uang tunai atau kas dari berbagai jenis transaksi yang terjadi pada perusahaan [3]

\section{HASIL}

\subsection{Use Case Diagram}

Kebutuhan pengguna yang telah diuraikan pada tahapan analisis kebutuhan pengguna untuk aplikasi pengolahan penerimaan dan pengeluaran kas pada CV. Malianury Grafiti akan dimodelkan menjadi use case diagram. Adapun Use Case Diagram tersebut yaitu sebagai berikut:

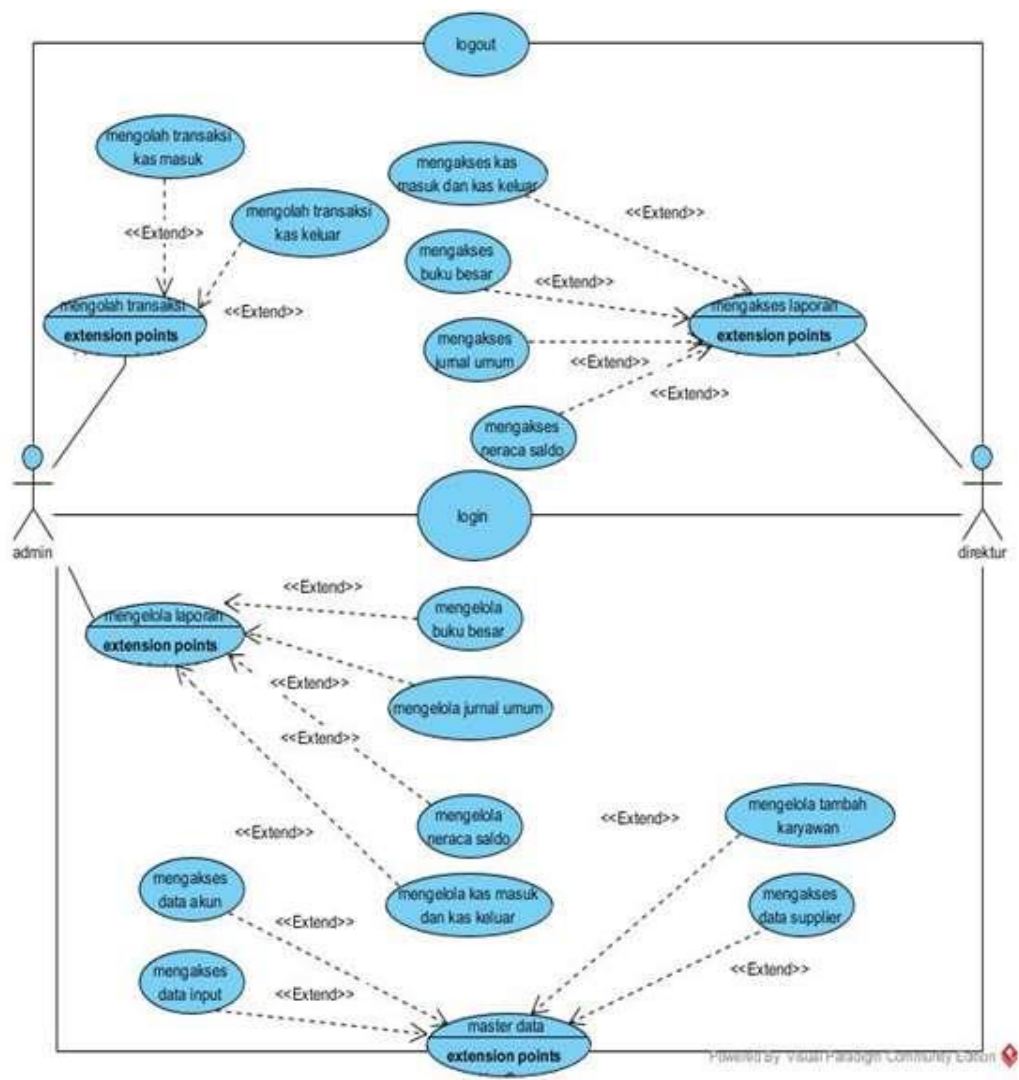

Sumber: Hasil Penelitian (2020)

Gambar 1. Use Case Diagram Sistem Informasi Akuntansi Penerimaan dan Pengeluaran Kas

\subsection{Activity Diagram}

Activity diagram merupakan diagram yang menggambarkan aktifitas-aktifitas sistem dimana setiap urutan aktifitas yang digambarkan merupakan proses bisnis sistem yang didefinisikan. Setiap use case pada use case diagram ini akan dijelaskan proses bisnisnya menggunakan activity diagram. Activity diagram untuk setiap kegiatan dari aplikasi pengolahan penerimaan dan pengeluaran kas pada CV. Malianury Grafiti digambarkan pada halaman berikut.

\section{Activity Diagram Login}

Pada activity diagram login ini terbagi dua hak akses sistem, yakni admin dan direktur. Berikut gambarnya. 


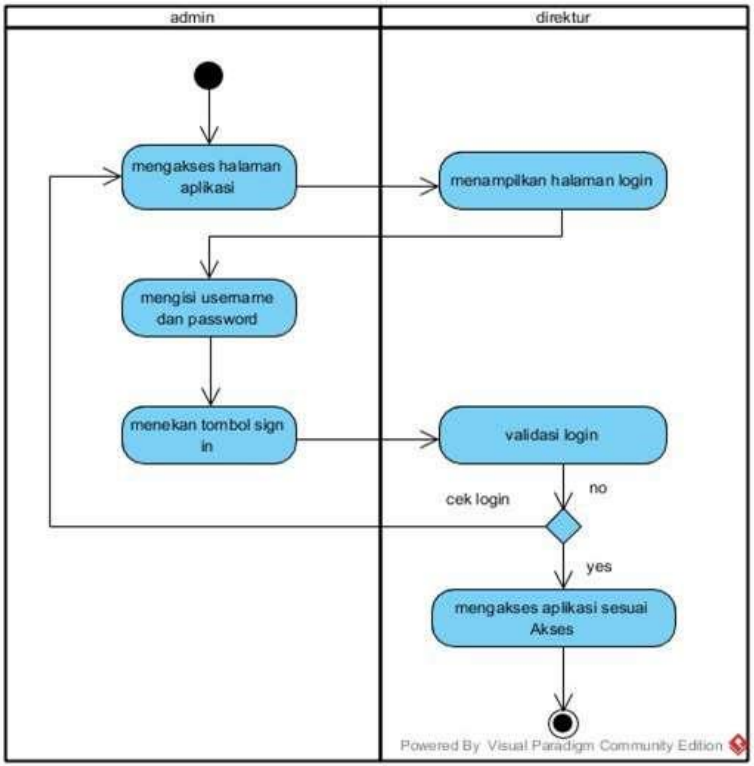

Sumber: Hasil Penelitian (2020)

\section{Gambar 2. Activity Diagram Login}

\section{Activity Diagram Penerimaan Kas}

Pada halaman ini, admin dapat mengelola data pendapatan mulai dari penambahan, pengubahan dan penghapusan data pendapatan atau penerimaan kas.

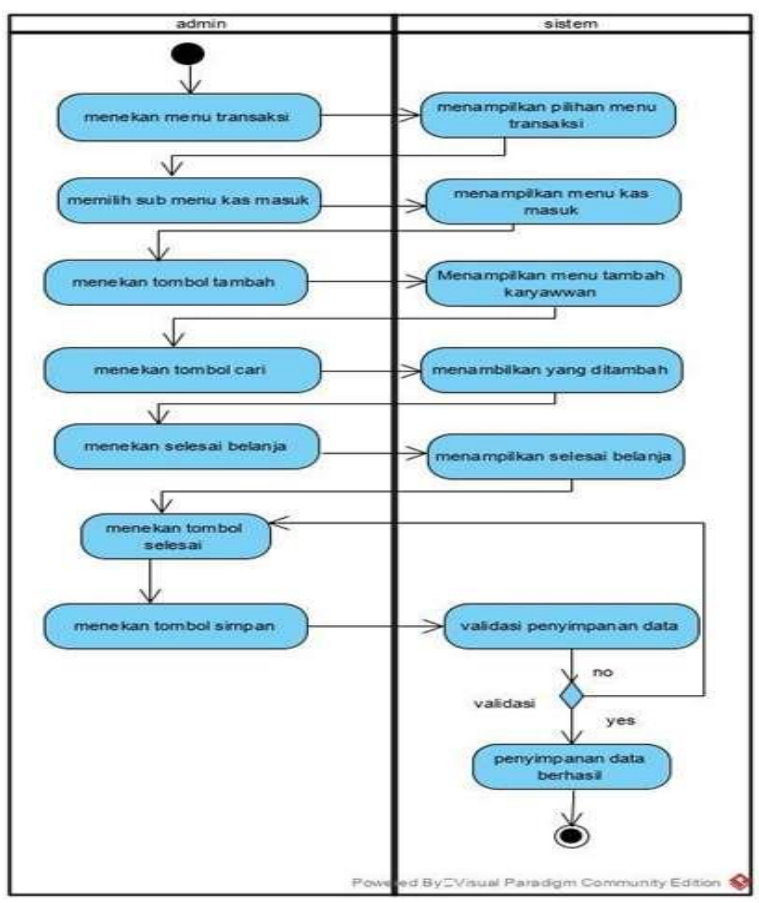

Sumber: Hasil Penelitian (2020)

Gambar 3. Activity Diagram Penerimaan Kas

\section{Activity Diagram Pengeluaran Kas}

Pada activity diagram di bawah ini digunakan untuk menampilkan segala aktivitas yang berkaitan dengan pencatatan transaksi pengeluaran kas. Berikut gambarnya. 


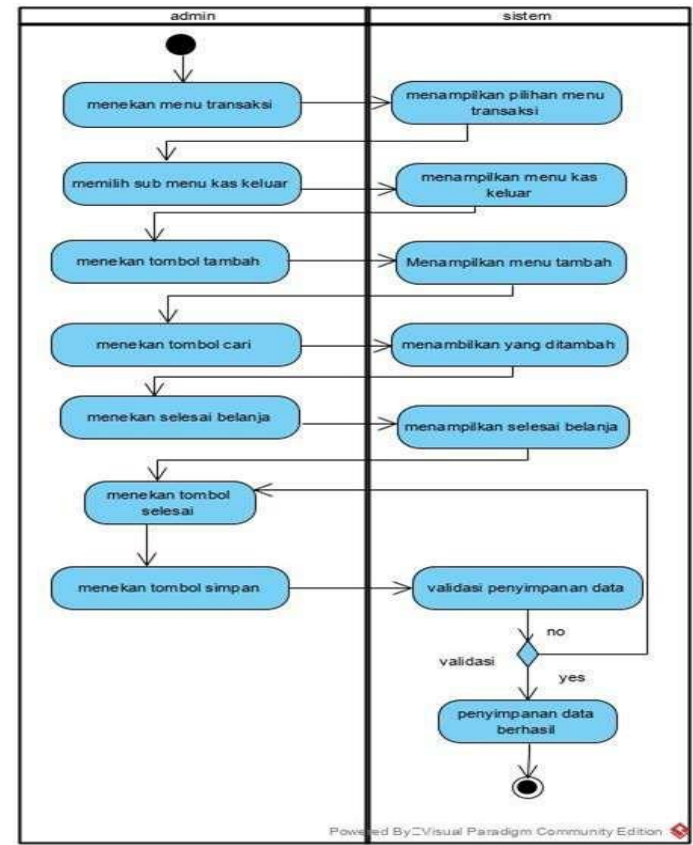

Sumber: Hasil Penelitian (2020)

\section{Gambar 4. Activity Diagram Pengeluaran Kas}

\subsection{User Interface}

User Interface merupakan tampilan visual yang menjembatani sistem dengan pengguna. Berikut ini adalah hasil tampilan antar muka atau user interface yang disediakan untuk level pengguna admin.

1. Tampilan Login

Pada halaman login, pengguna harus mengisi username dan password untuk dapat mengakses aplikasi. Apabila berhasil maka user dapat mengakses halaman menu utama atau dashboard.

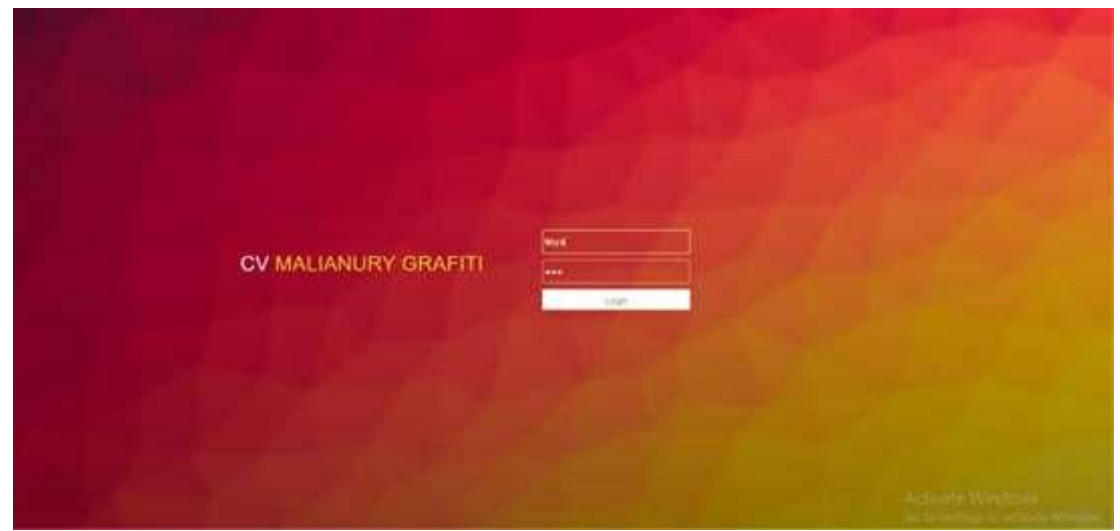

Sumber: Hasil Penelitian (2020)

\section{Gambar 5. Tampilan Login}

2. Tampilan Menu Dashboard

Halaman dashboard admin ini dapat diakses apabila admin telah melewati proses login. Pada halaman dashboard admin ini menyediakan master data, data transaksi, mengakses laporan dan logout. 


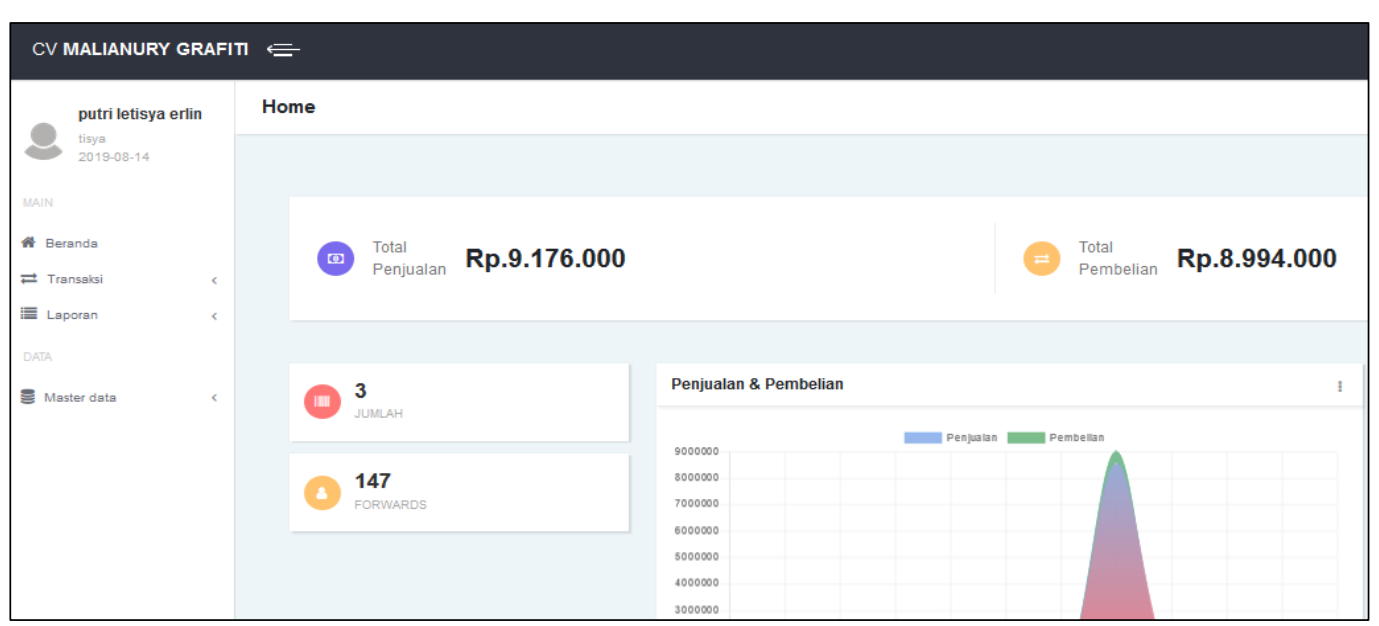

Sumber: Hasil Penelitian (2020)

\section{Gambar 6. Tampilan Menu Dashboard}

3. Tampilan Menu Penerimaan Kas (Kas Masuk)

Pada menu penerimaan kas ini dapat dilakuka tambah data pendapatan dapat diakses apabila admin menekan tombol tambah data. Admin dapat menambah data pendapatan dengan cara mengisi kolom yang tersedia dan menekan tombol simpan.

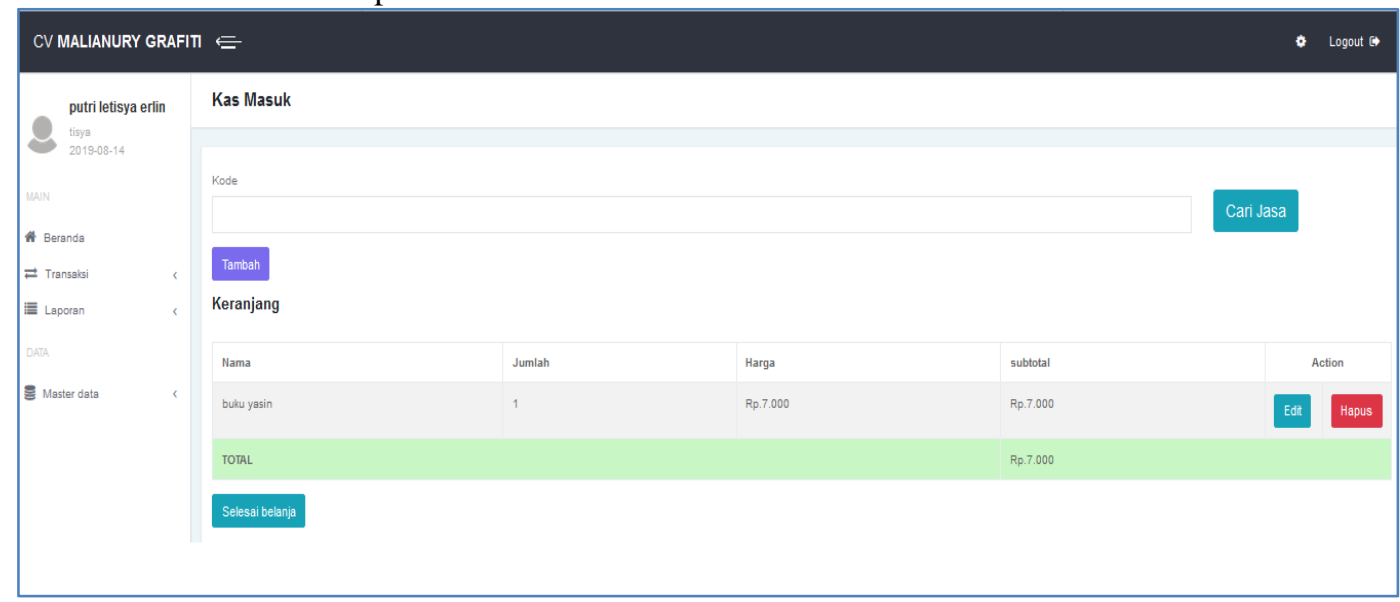

Sumber: Hasil Penelitian (2020)

Gambar 7. Tampilan Menu Penerimaan Kas

4. Tampilan Menu Pengeluaran Kas (Kas Keluar)

Pada halaman menu pengeluaran kas ini admin dapat mengelola data pembayaran mulai dari penambahan, pengubahan dan penghapusan data pembayaran. 


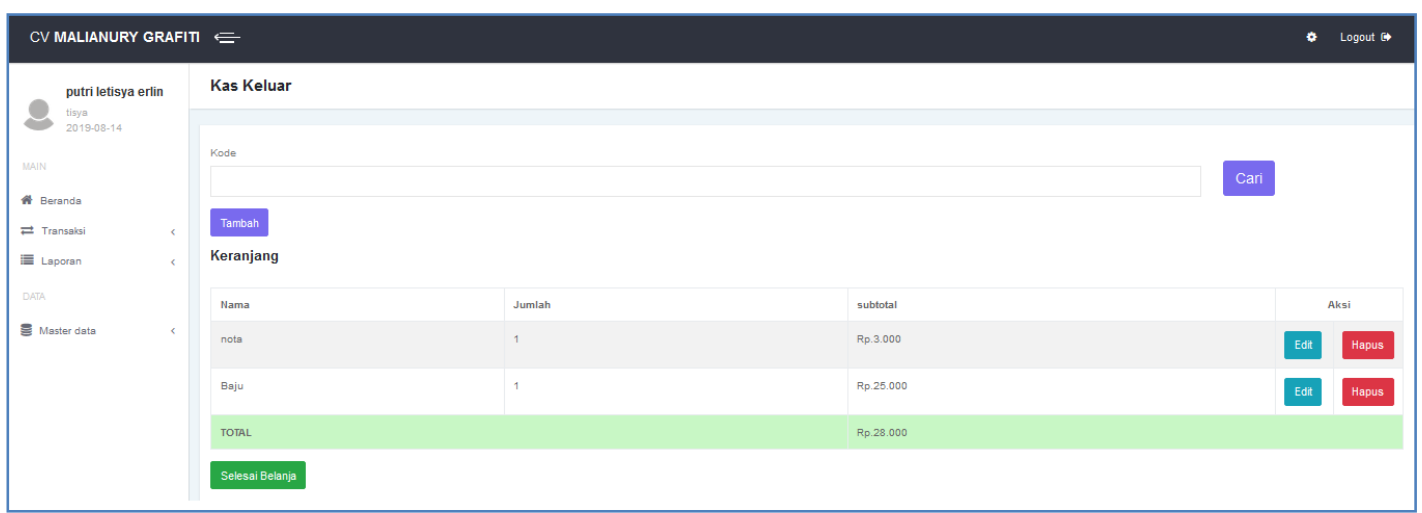

Sumber: Hasil Penelitian (2020)

\section{Gambar 8. Tampilan Menu Pengeluaran Kas}

5. Tampilan Menu Jurnal Umum

Pada halaman laporan jurnal umum, admin dapat melihat atau mengakses laporan jurnal umum sesuai dengan periode bulan dan tahun.

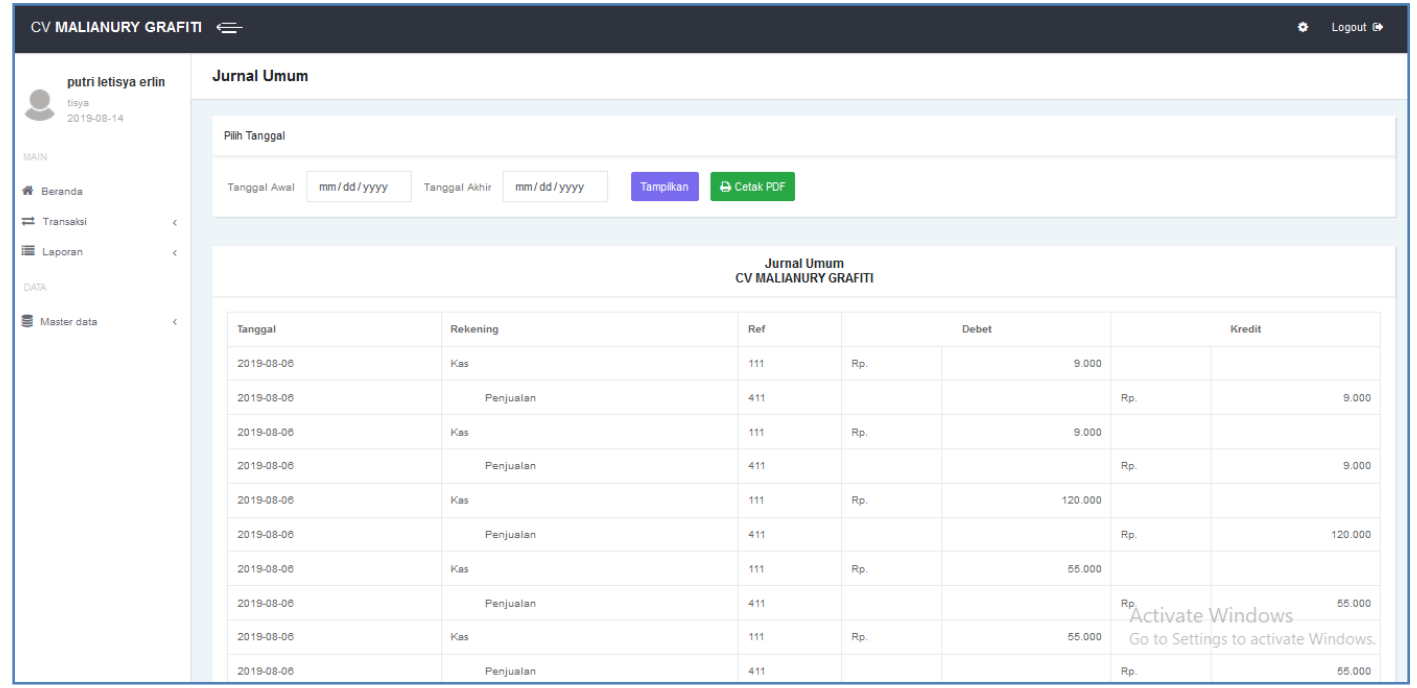

Sumber: Hasil Penelitian (2020)

Gambar 9. Tampilan Menu Jurnal Umum

6. Tampilan Menu Neraca Saldo

Pada halaman laporan neraca saldo, admin dapat melihat atau mengakses laporan neraca saldo sesuai dengan periode bulan dan tahun. Berikut tampilannya. 


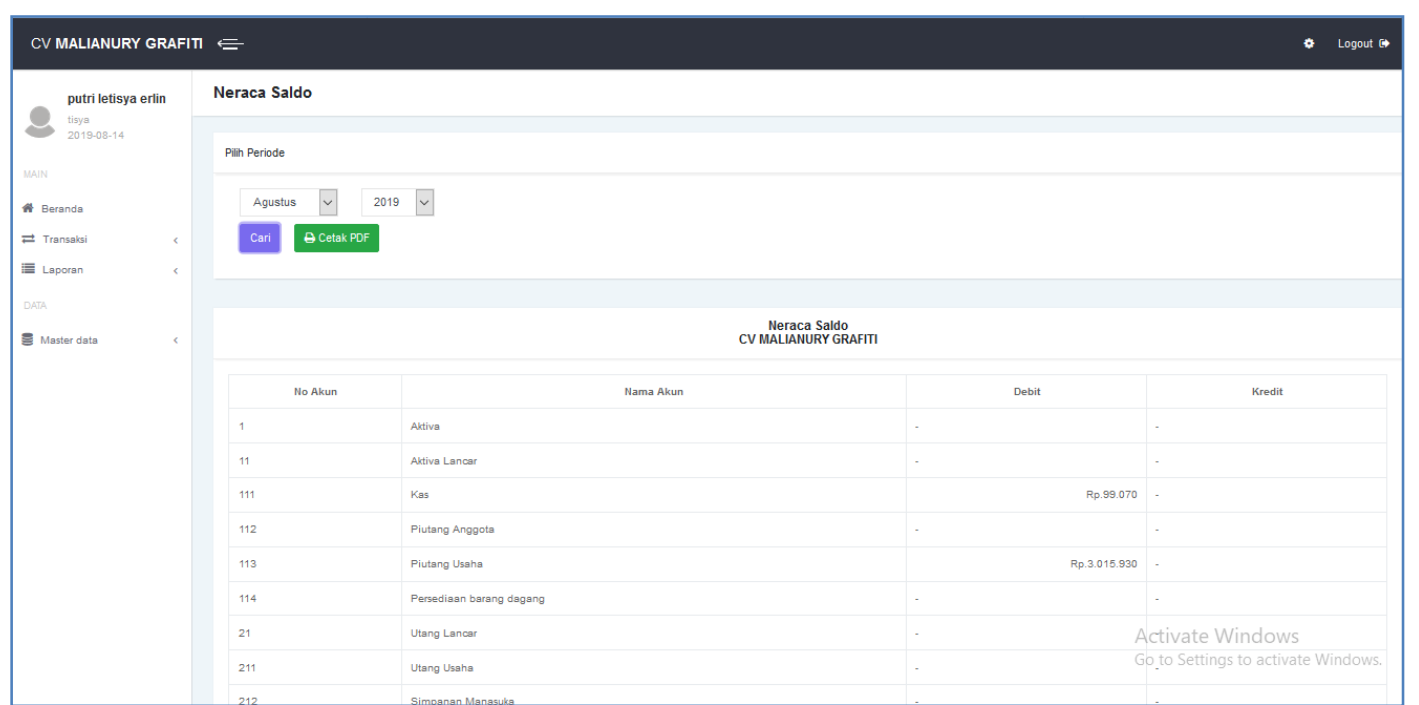

Sumber: Hasil Penelitian (2020)

\section{Gambar 9. Tampilan Menu Neraca Saldo}

7. Tampilan Menu Buku Besar

Pada halaman buku besar ini, admin dapat melihat atau mengakses buku besar dari setiap rekening akun.

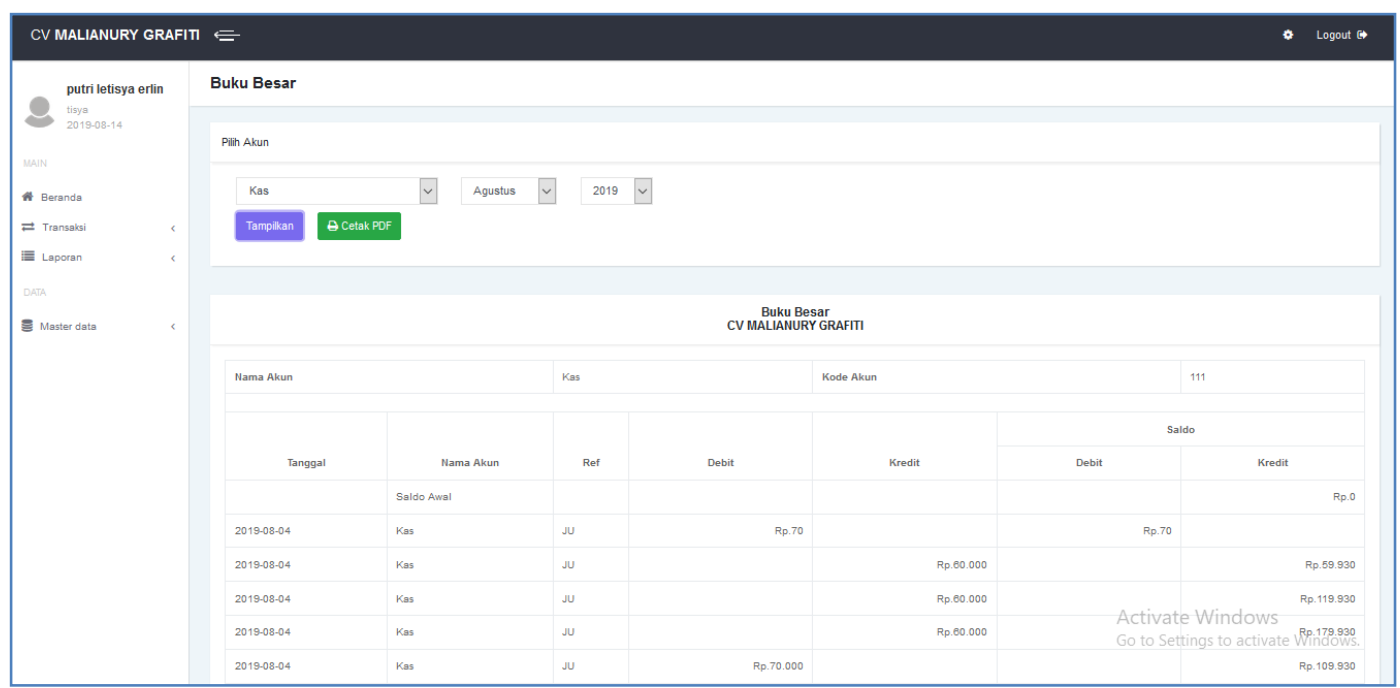

Sumber: Hasil Penelitian (2020)

\section{Gambar 10. Tampilan Menu Buku Besar}

8. Tampilan Menu Laporan Arus Kas

Pada halaman laporan arus kas, admin dapat melihat atau mengakses laporan arus kas sesuai dengan periode bulan dan tahun. 


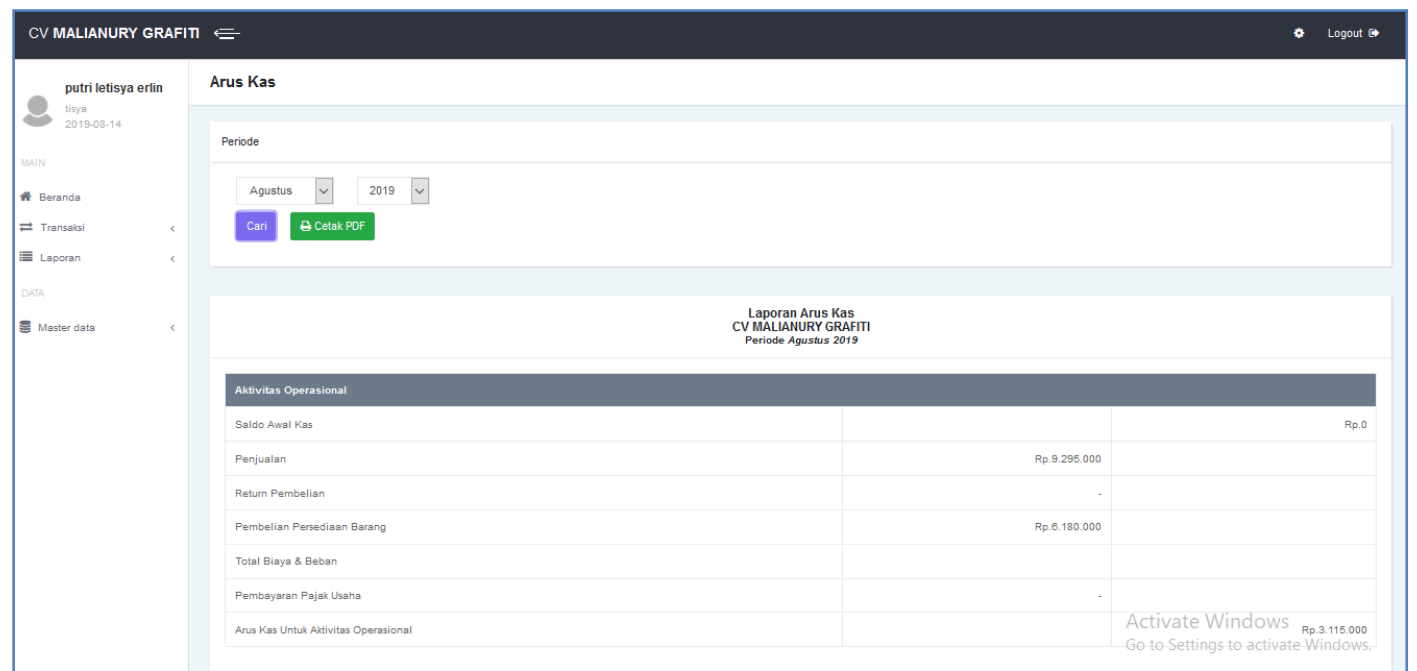

Sumber: Hasil Penelitian (2020)

\section{KESIMPULAN}

Gambar 11. Tampilan Laporan Arus Kas

Berdasarkan hasil pembahasan yang telah diuraikan pada bab sebelumnya mengenai sistem informasi akuntansi penerimaan dan pengeluaran kas dapat disimpulkan bahwa:

a. Sistem informasi akuntansi yang dibuat ini dapat membantu user dalam mengelola transaksi penerimaan dan pengeluaran kas yang sistematis (computerized) hingga pada laporan keuangan.

b. User lebih cepat dan akurat dalam mengelola data dengan aplikasi tersebut sehingga meminimalisir kesalahan-kesalahan pencatatan.

\section{REFERENSI}

[1] N. Cahyaningsih and I. S. Putra, "Efektivitas Pengendalian Internal Kas Melalui Evaluasi Sistem Informasi Akuntansi Penerimaan Kas,” J. Chem. Inf. Model., vol. 53, no. 9, pp. 1689-1699, 2019, [Online]. Available: https://journal.stieken.ac.id/index.php/ritmik/article/view/260.

[2] R. A.S. and Shalahuddin, "Rekayasa Perangkat Lunak Terstruktur dan Berorientasi Objek," Bandung: Informatika, 2016.

[3] A. Anna, N. Nurmalasari, and A. E. Yusnita, "Rancang Bangun Sistem Informasi Akuntansi Penerimaan dan Pengeluaran Kas pada Kantor Camat Pontianak Timur," J. Khatulistiwa Inform., vol. 6, no. 2, pp. 107-118, 2018, doi: 10.31294/khatulistiwa.v6i2.153.

[4] Anna, "Aplikasi Kamus Bahasa Indonesia - Bugis Berbasis Web Dengan Metode Sequential Search," J. Inform., vol. 3, no. September, pp. 246-258, 2016, [Online]. Available: https://repository.bsi.ac.id/index.php/repo/viewitem/1215.

[5] N. Nurmalasari, A. Anna, and F. Ilmi, "Sistem Informasi Kas Masuk Dan Kas Keluar Berbasis Web Pada Pt Rakha Rekananta Pontianak," Swabumi, vol. 8, no. 1, pp. 59-70, 2020, doi: 10.31294/swabumi.v8i1.7433.

[6] S. Mukjizatiah and A. Arisman, "Analisis Sistem Informasi Akuntansi Penerimaan Dan Pengeluaran Kas Pada Pt Mardiatama Konstruksi Palembang," J. Ilmiah. STIE Multi Data Palembang, pp. 1-13, 2016. 